\title{
Prevalence of Depression among elderly population: A cross- sectional study
}

\author{
Rai N1, Pokhrel P1', Shakya DR², Sapkota N³, Basnet M+4, Sharma PP5
}

1. Lecturer, Department of Psychiatry, Kist Medical College, Kathmandu, Nepal 2. Professor, Department Of Psychiatry, BPKIHS, Dharan, Nepal 3. Additional Professor, Department Of Psychiatry, BPKIHS, Dharan, Nepal 4. Associate Professor, Department Of Psychiatry, BPKIHS, Dharan, Nepal 5. Professor, Department Of Psychiatry, Kist Medical College, Kathmandu, Nepal

E-mail *Corresponding author : raineena15@gmail.com

\begin{abstract}
Introduction: The elderly population is on rise in Nepal. With increasing elderly population, the burden of elderly health problems is also increasing. The number of mentally ill elderly is on rise. Studies have shown Depression is most common psychiatric illness in geriatric population 3 which has a significant impact in quality of life of elderly people.This study was carried out to examine the prevalence of Depression among elderly population visiting psychiatric services and severity of illness.

Material And Method: It is a descriptive, cross sectional, hospital based study. A total of 60 patients of age 60 and above, attending psychiatric services were enrolled after due written informed consent. The study period was 6 months (2012-2013). A semi-structured proforma was used to collect information about the socio-demographic profiles of patients. Diagnosis was made based on International Classification of Diseases (ICD-10) criteria after discussion and assessment of the case with the consultant psychiatrist.

Results: The maximum number of patients was in the age group of 60-69 $(n=43,71.7 \%)$. The mean age was 68.18 . The predominant caste was "caste origin hill hindu group" $(n=30,50.0 \%)$. Maximum cases were Hindu $(n=45$, $75.0 \%)$ by religion. Majority of the subjects were female $(n=36,60.0 \%)$. Most of the subjects were married ( $n=48$, $80 \%)$ and were from middle socio economic status $(n=44,73.3 \%)$ and majority $(n=35,58.33 \%)$ of the patients were illiterate. The prevalence of depression was 50.0\%. Among them majority were suffering from moderate depressive episode $(n=15,53.6 \%)$. Majority of them were female. Among the 30 depressive patients, 11 (36.7\%) patients had positive family history of mental illness. Among the mental illness, Mood disorder ( $n=5,45.5 \%)$ and anxiety disorder $(n=3,27.3 .0 \%)$ were found to be the most.
\end{abstract}

Conclusion: Overall findings suggest that prevalence of depression is common, so further research is required to understand the gravity of situation.

Keywords: Depression, Elderly, Nepal

\section{INTRODUCTION}

The elderly population is on rise in Nepal. There were 1.5 million in 2001 and 2.1million in 2011 which constitute $6.5 \%$ and $8.1 \%$ of the total population. ${ }^{1}$ With increasing elderly population, the burden of elderly health problems is also increasing; it may be physical or mental. Many a times psychological problems are neglected giving more preference to physical illnesses. The number of mentally ill elderly is on rise. ${ }^{2}$ Studies have shown Depression is most common psychiatric illness in geriatric population 3 which has a significant impact in quality of life of elderly people. Taking care of that, this study 
will attempt to find the prevalence of depression among elderly population.

\section{MATERIAL AND METHOD}

It is a descriptive, cross sectional, hospital based study conducted at B.P Koirala institute of health sciences Dharan. A total of 60 patients of age 60 and above, attending psychiatric service, including out-patient (OPD), inpatient and consultation liaison service, were enrolled after due written informed consent. The study period was 6 months (2012-2013). A semi-structured proforma developed by department of psychiatry was used to collect information about the socio-demographic profiles of patients. Diagnosis was made based on International Classification of Diseases (ICD-10) criteria. Patient with organic mental disorder, uncooperative and age below 60 were excluded. The aim of the study was to study prevalence of depression and Clinico-demographic profiles of the geriatric patients attending psychiatric services. The ethical approval for the study was obtained from the Institute's Ethical Board. The data was analyzed using SPSS.

\section{RESULT}

The maximum number of patients was in the age group of $60-69(n=43,71.7 \%)$; followed by the age group $70-79(n=13,21.7 \%)$. The mean age was 68.18. The predominant caste was "caste origin hill hindu group" ( $\mathrm{n}=30,50.0 \%)$ followed by "Janjati" $(\mathrm{n}=22,36.7 \%)$. Maximum cases were Hindu $(n=45,75.0 \%)$ by religion followed by kirat $(n=12,20.3 \%)$. Majority of the subjects were female $(n=36,60.0 \%)$. Most of the subjects were married $(n=48,80 \%$. Most of them were from middle socio economic status $(\mathrm{n}=44,73.3 \%)$ and majority $(n=35,58.33 \%)$ of the patients were illiterate.

The overall prevalence of depression was $50.0 \%$. Among them majority were suffering from moderate depressive episode $(n=17,56.7 \%)$. Majority of the depressive patients were female. Among the 30 depressive patients, 11 (36.7\%) patients had positive family history of mental illness. Among the mental illness, Mood disorder $(n=5,45.5 \%)$ and anxiety disorder $(n=3$, 27.3.0\%) were found to be the most.

\section{Table 1: Socio-Demographic Profile of Patients}

\begin{tabular}{|c|c|c|}
\hline Characteristics & Catagory & Number(\%) \\
\hline Age(in years) & $\begin{array}{l}60-69 \\
70-79 \\
80 \text { and above }\end{array}$ & $\begin{array}{l}43(71.7) \\
13(21.7) \\
4(6.6)\end{array}$ \\
\hline Caste & $\begin{array}{l}\text { Origin hill hindu } \\
\text { group } \\
\text { Origin terai hindu } \\
\text { group } \\
\text { Newar } \\
\text { Janajati }\end{array}$ & $\begin{array}{l}30(50.0) \\
4(6.7) \\
4(6.7) \\
22(36.7)\end{array}$ \\
\hline Sex & $\begin{array}{l}\text { Female } \\
\text { Male }\end{array}$ & $\begin{array}{l}36(60.0) \\
24(40.0)\end{array}$ \\
\hline Religion & $\begin{array}{l}\text { Hindu } \\
\text { Kirat } \\
\text { Buddhist }\end{array}$ & $\begin{array}{l}45(75.0) \\
12(20.3) \\
3(5.0)\end{array}$ \\
\hline $\begin{array}{l}\text { Socio economic } \\
\text { status }\end{array}$ & $\begin{array}{l}\text { Low } \\
\text { Middle } \\
\text { High }\end{array}$ & $\begin{array}{l}12(20.0) \\
44(73.3) \\
4(6.7)\end{array}$ \\
\hline Marital status & $\begin{array}{l}\text { Married } \\
\text { Separated } \\
\text { Widow/er }\end{array}$ & $\begin{array}{l}48(80.0) \\
6(10.0) \\
6(10.0)\end{array}$ \\
\hline \multirow[t]{2}{*}{ Education } & $\begin{array}{l}\text { Illiterate } \\
\text { Primary } \\
\text { Secondary }\end{array}$ & $\begin{array}{l}35(58.3) \\
15(24.6) \\
7(11.5)\end{array}$ \\
\hline & Higher secondary & $3(4.9)$ \\
\hline Occupation & $\begin{array}{l}\text { Ex-Serviceman } \\
\text { Farmer } \\
\text { Teaching } \\
\text { House wife }\end{array}$ & $\begin{array}{l}13(21.7) \\
17(28.3) \\
5(8.3) \\
25(41.7)\end{array}$ \\
\hline
\end{tabular}

Table 1: Prevalence Of Depression in Subjects

\begin{tabular}{|l|l|l|}
\hline Diagnosis & Frequency(n) & Percent(\%) \\
\hline Depression & 30 & $50.0 \%$ \\
\hline Mild depression & 5 & 16.7 \\
Moderate depression & 17 & 56.7 \\
Severe depression & 8 & 26.7 \\
\hline
\end{tabular}


Fig 1. Showing Distribution Of Depressive Patients By Gender

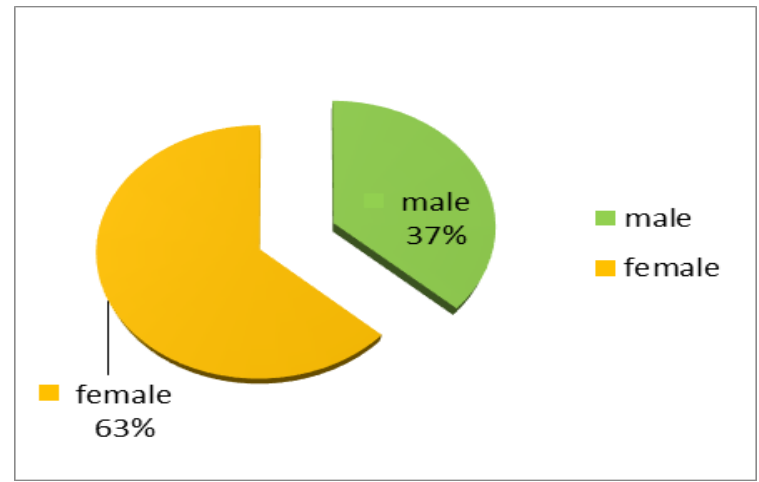

Table 3: Distribution of subjects by family history of mental illness:

\begin{tabular}{|l|l|l|l|}
\hline Characteristics & Category & $\begin{array}{l}\text { Frequency } \\
(\mathrm{n})\end{array}$ & $\begin{array}{l}\text { Percent } \\
(\%)\end{array}$ \\
\hline \multirow{2}{*}{ Mental illness } & Present & 11 & $36.7 \%$ \\
\cline { 2 - 4 } & Absent & 19 & $63.3 \%$ \\
\hline Total & & 30 & 100 \\
\hline
\end{tabular}

Fig 2: Distribution of different psychiatric illness in family:

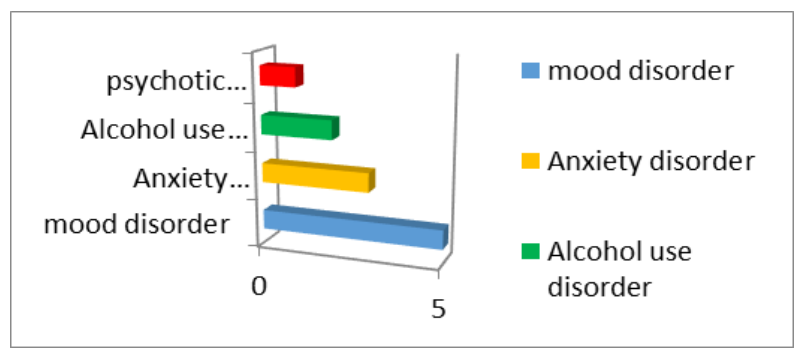

\section{DISCUSSION:}

In our study most of the patients were caste origin hill hindu group $(50.0 \%)$ followed by Janajati $(36.7 \%)$. This study keeps parallel with the study conducted by Shakya Dr et al. ${ }^{4}$ Among the patients visited mostly patients were in the age group of $60-69$ years(71.1\%). Mean age of the patients was 68.18 years. This finding is similar with the study by Kumar A, Sharma et al. ${ }^{5}$ and the study conducted in rural community of west Bengal India. ${ }^{6}$ This demonstrate that more illnesses in the younger elderly age group this could be because younger elderly age group were likely to visit the health facility when compare to very elderly group because of better physical strength.

In our study, female geriatric patient outnumbered the male geriatric patient. This findings is similar to study in community setting in India and by choudhary et al. ${ }^{7}$ However this findings is in contrast to the study by Singh et al. ${ }^{8}$ with male preponderance. Majority of the subjects were married $(80.0 \%)$. This finding is consistent with that from the study conducted in tertiary care hospital in Goa, India. ${ }^{9}$ This could be because of increased life expectancy of couple and better support system due to availability of significant figure in their life. Most of the patients were illiterate and were from the middle socioeconomic status. This finding is consistent with the findings by Singh et al. In our study among the enrolled patients, there was a predominance of Depression $(n=30$, $50.0 \%$ ). This findings is similar to the study conducted in Udupi Karnataka where the prevalence of depression was found to be $48 \% .{ }^{10}$ and the study by Adshead et al. ${ }^{11}$ Reason of high prevalence of depression among geriatric population could be the biological factor, psychological as well as social factor. Moderate depressive episode was most common in our study which is parallel with the study by Udupi.

\section{CONCLUSION:}

Overall findings suggest that prevalence of depression is common, so further research is required to understand the gravity of situation.

\section{REFERENCES:}

1) Bhattarai, N. Nepal's ageing population: Are we prepared for elderly care? Retrieved on May 06, 2012. Available from: http:// www.nepalnews.com/home/index.php/guestcolumn/18567nepals-ageing-p.

2) Rosen $A$. The shortage of an adequately trained geriatric mental health workforce January 24,2005. Available athttp//www.whcoa.gov/(accessed Jan 2, 2010)

3)Nehru Ritu, Chakrabarti Subho et al. Comparission of Cognitive Function between first and multi-episode Affective Bipolar Disorder.Journal of affective Disorder 2006;93:185-192.

3)khatri Jb, Nepal MK et al.Study of depression among bgeriatric population in Nepal. Nepal Med Coll J. 2006 Dec; 8(4):220-3

4) Shakya DR. clinical Profile of Elderly Psychiatry Outpatients.XVI Scientific Programme, Abstract book,November, 2009,pp 108 
5) Kumar A, Sharma SR et al. High prevalence of Depression and Anxiety symptoms among hospitalized geriatric medical inpatients: A study from a Tertiary level hospital in Nepal. UTMJ. Vol.88, number 1, December 2010

6) Nandi P.S, Banarjee A et al. A study of psychiatric morbidity of elderly population of a rural community in west Bengal. Indian Journal Psychiatry; 1997, 39(2) 122129.

7) Grover S, Malhotra N Depression in elderly: A review of Indian research. J Geriatr Ment Health 2015; 2:4-15,47)

8) Singh G Chavan B et al. Geriatric outpatient with psychiatric illnesss in a teaching hospital setting- a Retrospective study. Indian Journal of Psychiatry; 2004, 46(2) 140-143.

9) Pereira Y.D Estibeiro A et al. Geriatric patients attending tertiary care psychiatric hospital. Indian Journal of Psychiatry. 2002,44(4), 326-331.

10) Lena A, Ashok K, Padma M, RamathV, Kamath A. Health and social problems of the elderly :A crossectional study in udupitaluk Karnataka. Indian J Community Med. 2009;34(2):131-4.

11)AShead F, Day Cody D et al.BASDEC: A novel screening instrument for depression in elderly medical inpatients. Br Med J. 1992;305:392. 